\title{
The Corporate Governance Effects of Audit Committees
}

\author{
STUART TURLEY and MAHBUB ZAMAN \\ School of Accounting and Finance, University of Manchester, Manchester M13 9PL, UK, \\ E-mail: \{stuart.turley; mahbub.zaman\}@man.ac.uk
}

\begin{abstract}
Arguments associated with the promotion of audit committees in many countries are premised on their potential for alleviating weaknesses in corporate governance. This paper provides a synthesis and evaluation of empirical research on the governance effects associated with audit committees. Given recent policy recommendations in several countries aimed at strengthening these committees, it is important to establish what research evidence demonstrates about their existing governance contribution.

A framework for analyzing the impact of audit committees is described, identifying potential perceived effects which may have led to their adoption and documented effects on aspects of the audit function, on financial reporting quality and on corporate performance. It is argued that there is only limited and mixed evidence of effects to support claims and perceptions about the value of audit committees for these elements of governance. It is also shown that most of the existing research has focused on factors associated with audit committee existence, characteristics and measures of activity and there is very little evidence on the processes associated with the operation of audit committees and the manner in which they influence organizational behaviour.

It is clear that there is no automatic relationship between the adoption of audit committee structures or characteristics and the achievement of particular governance effects, and caution may be needed over expectations that greater codification around factors such as audit committee members' independence and expertise as the means of "correcting" past weaknesses in the arrangements for audit committees. The most fundamental question concerning what difference audit committees make in practice continues to be an important area for research development. For future research we suggest (i) greater consideration of the organizational and institutional contexts in which audit committees operate; (ii) explicit theorization of the processes associated with audit committee operation; (iii) complementing extant research methods with field studies; and (iv) investigation of unintended (behavioural) as well as expected consequences of audit committees.
\end{abstract}

Key words: accountability, audit committee effectiveness, audit committee research, corporate governance

\section{Introduction}

During the last two decades audit committees (henceforth ACs) have become a common mechanism of corporate governance internationally. Originally 
non-mandatory structures used by a minority of corporations, more recently numerous official professional and regulatory committees in many countries have recommended their more universal adoption and have advocated expanded roles for ACs. The Sarbanes-Oxley Act of 2002 in the US, the report of the Australian Treasury (2002) and the recommendations of the Smith Committee (2003) and the Higgs (2003) review in the UK (Turley and Zaman, 2003) are recent examples. The objective of this paper is to evaluate the extent to which research evidence demonstrates corporate governance effects associated with the operation of ACs in private sector corporations ${ }^{1}$. This evaluation incorporates consideration of perceived effects that may have led to AC adoption and demonstrated effects on the audit function, financial reporting quality and corporate performance.

While no a priori position on the efficacy of ACs for alleviating weaknesses in corporate governance is adopted in this paper, it can be noted that regulators, governmental bodies and researchers in many countries have raised questions about ACs' effectiveness and their contribution to governance (Sommer, 1991; Wolnizer, 1995; Lee, 2001; Turner, 2001). The incidence of high profile corporate failures, notably in the period since 2000 , involving fraud, poor accounting and failure of internal control have provided at least anecdotal evidence to support concerns about the adequacy of the monitoring provided by ACs. Such events have accentuated concerns that have been expressed over a somewhat longer period. For example, researchers and commentators have argued that many AC members lack critical attributes such as independence, expertise and experience in oversight (Vicknair et al., 1993; DeZoort, 1997; Cohen et al., 2002; Guy and Zeff, 2002), that the level of interaction between the AC and auditors is variable, undermining the AC's value as an effective vehicle for pursuing shareholders' interests (Hatherly, 1999), and that whether ACs are actually discharging their important responsibilities is not sufficiently understood (Kalbers and Fogarty, 1993). Some have also argued that the adoption of ACs may be primarily symbolic (Kalbers and Fogarty, 1998) and that the benefits associated with them are more rhetorical than substantive (DeZoort, 1997).

Recent years have seen attempts to enhance the role of ACs to address governance issues (for example, Cadbury (1992) in the UK, AARF (1997) in Australia and the Blue Ribbon Committee (1999) in the US), followed by significant corporate failures such as Enron in which the adequacy of the AC has been questioned (Powers, 2002; Benston and Hartgraves, 2002), followed in turn by further attention to ACs' responsibilities and the qualities necessary for AC effectiveness (see for example, Sarbanes-Oxley and SEC (2002) in the US, Australian Treasury (2002) and Smith (2003) in the UK). Given, on the one hand, the continued reliance on and development of rules for ACs in the governance policy arena and, on the other hand, the concerns expressed about the realization of the intended benefits from having ACs as part of the 
governance structure for corporations, the question of what is the impact of ACs on specific aspects of governance in practice is of considerable importance. It is this question that this paper seeks to address by evaluating available empirical evidence about the impact of ACs on a number of governance factors. While the governance environment continues to change in the aftermath of Enron and similar cases, evaluation of existing demonstrated effects associated with ACs is relevant in forming expectations about the likely results of current regulatory change, in establishing benchmarks against which the future impact of such change can be evaluated and in guiding the emphasis of future research.

The remainder of the paper is structured as follows. The next section sets out a framework of potential areas of impact within which the evidence on the corporate governance effects of ACs can be evaluated. Section 3 establishes the evidence of AC impact - perceived incentives associated with their adoption, effects on the audit function, effects on financial reporting quality and effects on corporate performance. Section 4 provides a summary of the evaluation of evidence, concluding remarks and suggestions for future research.

\section{A Framework for Reviewing Audit Committee Effects}

The concept of ACs is not new (see, for example, Tricker (1978), Collier (1996), DeZoort(1997) and Lee and Stone (1997), for evidence on their development). What is notable, however, is the extent of their promotion and subsequent adoption by listed companies in several countries during the last quarter century (Morse and Keegan, 1999). There have been major changes over time in the context in which ACs operate and cultural and structural differences internationally will influence their operation, but overall there has been an increasing degree of codification and harmonization of "best practice". The growing global acceptance of the AC as a relevant governance structure, including recent efforts towards increasing legislation, in a wide variety of environments can be linked to claims made in professional and governmental reports about AC benefits on a number of aspects of corporate governance (see Appendix 1 for examples of such statements). These potential areas of expected benefit can be used to establish a broad framework for evaluating the evidence on effects associated with the existence and operation of ACs. This framework of impact issues is set out in Table I.

\subsection{STRUCTURAL INCENTIVES}

Arguments associated with the promotion of ACs emphasize their potential contribution to, for example, the relationships between directors, investors and auditors, the discharge of accountability and directors' execution of their 
Table I. A framework of expected AC effects

\begin{tabular}{ll}
\hline Area of Impact & Examples of effects \\
\hline Structural incentives & $\begin{array}{l}\text { Factors associated with AC adoption and potential reduction } \\
\text { in agency costs } \\
\text { Links with other governance arrangements, e.g. large } \\
\text { audit firms } \\
\text { Reduction in directors' legal liability } \\
\text { Selection and remuneration } \\
\text { Independence of external auditors } \\
\text { Ampact on the audit process and on auditor communication } \\
\text { Monitoring of internal control and audit } \\
\text { Financial } \\
\text { reporting quality } \\
\text { Impact on errors and irregularities } \\
\text { Adoption of accounting standards and accounting policy choice } \\
\text { Legal/regulatory action for defective reporting } \\
\text { Audit qualifications } \\
\text { Impact of AC adoption on share prices and wealth creation }\end{array}$ \\
\hline
\end{tabular}

responsibilities. They suggest ACs influence the balance of power in accountability and audit relationships. Whether or not this interpretation is valid, not least in terms of perceived or implied benefits, may be revealed by the circumstances that are associated with adoption (and non-adoption) of AC structures or particular AC characteristics such as level of expertise and independence. Although such factors do not in themselves provide evidence of actual effects in practice, it can indicate something about the motivations associated with ACs in governance structures and the organizational circumstances in which accountability benefits are most strongly perceived. Studies of the factors associated with formation in non-mandatory settings can thus provide evidence on the expected effects of ACs and the justification for $\mathrm{AC}$ requirements.

\subsection{EFFECTS ON THE AUDIT FUNCTION}

A second aspect of the case for ACs is their impact on external audit and internal control and audit. It has often been as a consequence of reviews of alleged weakness in audit effectiveness that recommendations for AC requirements have been made and actual outcomes in this area are therefore an important subject for evaluation. The potential for ACs to influence a number of factors concerning external and internal audit is asserted in professional literature and in policy documents. It is therefore appropriate to consider what evidence is available regarding the effects of ACs on the audit function in practice. ACs could be expected to have an impact on the 
appointment, removal and remuneration of auditors, the content and extent of audit work, auditor independence and the resolution of disputes between auditors and executive management. The evidence of the effects of ACs on the internal audit function and on internal controls and risk management also needs to be considered (Zaman, 2001). The AC can strengthen the internal audit function (COSO, 1994; Turnbull, 1999) and internal audit can in turn be an important resource to the $\mathrm{AC}$ in fulfilling its responsibilities. It is also argued that ACs should be responsible for overseeing management's assessment of business risk and that they can strengthen management's ability to identify and assess both internal and external risks and hence potential opportunities and challenges facing the entity in achieving its operating, financial, and compliance goals.

\subsection{EFFECTS ON FINANCIAL REPORTING}

ACs comment upon and approve choice of accounting policies, and they can be expected to influence a company's approach to financial reporting, levels of disclosure and adherence to standard practice. Over many years, various claims have been made about the potential contribution of ACs to improving financial reporting (Marsh and Powell, 1989; APB, 1994; ICAEW, 1997). ACs are expected to monitor the reliability of the company's accounting processes and compliance with corporate legal and ethical standards including the maintenance of preventive fraud controls. An interesting aspect of research on the financial reporting effects of ACs is the manner in which proxies for reporting quality are created, relying on both analysis of actual reported numbers and more negative signals of poor quality, such as regulatory action against companies.

\subsection{EFFECTS ON CORPORATE PERFORMANCE}

A fourth and final area of potential impact concerns whether the existence of an AC as a governance mechanism results in better corporate performance or wealth effects for investors. It may seem tenuous to draw a direct link between the AC and company performance, but recommended management and governance structures are intended to lead to improved control and better management practices, and this in turn could be associated with positive improvements in performance on behalf of investors.

The connection between particular governance structures and characteristics and corporate performance has become a notable theme in some recent research following corporate failures and it is therefore appropriate to examine whether this line of approach offers any insights and evidence on the value of ACs in companies. 


\section{Effects of Corporate Audit Committees}

This section of the paper evaluates the extent to which empirical research provides evidence of ACs' governance impact in each of the four principal areas introduced above, i.e. (i) structural incentives for the adoption of ACs; (ii) effects on the audit function; (iii) effects on financial reporting quality; and (iv) impact on corporate performance.

\subsection{STRUCTURAL INCENTIVES}

Several studies have conceptualized AC formation in an agency framework (Jensen and Meckling, 1976; Fama and Jensen, 1983), and have examined the link between proxies for agency costs and AC presence in organizations where ACs have been introduced voluntarily. Essentially this strand of research looks for evidence that ACs are perceived as effective mechanisms for reducing agency costs. Several factors associated with agency costs have been tested, including company size, leverage, inter-corporate stockholding, national stock market listing and extent of managerial ownership, but examination of the incentives for $\mathrm{AC}$ formation using these variables has produced mixed results, as illustrated in Table II.

Table II. Illustrative studies AC adoption and activity in an agency framework

\begin{tabular}{|c|c|c|c|c|c|c|c|}
\hline \multirow[t]{2}{*}{ Variable } & \multicolumn{7}{|l|}{ Study } \\
\hline & $\begin{array}{l}\text { Pincus } \\
\text { et al. } \\
(1989)\end{array}$ & $\begin{array}{l}\text { Bradbury } \\
\text { (1990) }\end{array}$ & $\begin{array}{l}\text { Collier } \\
(1993)\end{array}$ & $\begin{array}{l}\text { Menon } \\
\text { and } \\
\text { Williams } \\
\text { (1994) }\end{array}$ & $\begin{array}{l}\text { Adams } \\
(1997)\end{array}$ & $\begin{array}{l}\text { Turpin } \\
\text { and } \\
\text { DeZoort } \\
\text { (1998) }\end{array}$ & $\begin{array}{l}\text { Collier } \\
\text { and } \\
\text { Gregory } \\
\text { (1999) }\end{array}$ \\
\hline Company size & $+\mathrm{SR}$ & NSR & NSR & NSR & $+\mathrm{SR}$ & $+\mathrm{SR}$ & NSR \\
\hline Leverage & NSR & NSR & $+\mathrm{SR}$ & NSR & $+\mathrm{SR}$ & NSR & NSR \\
\hline $\begin{array}{l}\text { Top tier } \\
\text { audit firm }\end{array}$ & $+\mathrm{SR}$ & NSR & NSR & NSR & & & $+\mathrm{SR}$ \\
\hline $\begin{array}{l}\text { Management } \\
\text { ownership }\end{array}$ & $-\mathrm{SR}$ & NSR & $-\mathrm{SR}$ & NSR & & NSR & \\
\hline Assets in place & & NSR & NSR & & NSR & & \\
\hline $\begin{array}{l}\text { Inter corporate } \\
\text { holdings }\end{array}$ & & $+\mathrm{SR}$ & & & & & \\
\hline Dominant CEO & & & NSR & & & & $-\mathrm{SR}$ \\
\hline $\begin{array}{l}\text { No of } \\
\text { shareholders }\end{array}$ & & & NSR & & & & \\
\hline $\begin{array}{l}\text { Stock market } \\
\text { listing }\end{array}$ & $+\mathrm{SR}$ & & & & & NSR & \\
\hline
\end{tabular}

Note: \pm SR: positive/negative significant relationship; NSR: no significant relationship. 


\subsubsection{Company size}

Tests of an association between company size and the formation of ACs have reported inconsistent findings and do not provide unequivocal support for the suggestion that reduction of agency cost is the primary factor in voluntary adoption of ACs. While some studies (Pincus et al., 1989; Adams, 1997) have found a significant positive relationship between company size and AC formation, others using similar definitions of size have not found any significant relationship (Bradbury, 1990; Collier, 1993; Menon and Williams, 1994). Size has been found to be significant in explaining firms' decisions to include a separate AC report in the annual report to shareholders but interestingly other agency variables were not found to be associated with such voluntary reporting (Turpin and DeZoort, 1998).

\subsubsection{Leverage}

Jensen and Meckling (1976) suggest that, because of the conflicting interests of managers and debtholders, higher leverage increases debtholders' need to monitor managers. Managers have incentives to control the agency cost of debt and can do so by providing increased monitoring through ACs. Again, as shown in Table II, the research evidence on the influence of leverage on the formation of ACs is inconclusive. For example, Pincus et al. (1989) found only mixed evidence that $\mathrm{AC}$ formation is associated with higher leverage and concluded that there is no strong support for an association between the agency cost of debt and voluntary AC formation. In a contrasting result, Collier (1993) asserted that his UK study is 'unique in highlighting gearing as a significant factor' (p.429). Although Adams (1997) provides some support for Collier's (1993) findings, other studies provide contrary evidence, failing to find a significant positive relationship between leverage and AC formation (Eichenseher and Shields, 1985; Bradbury, 1990; Menon and Williams, 1994). There is also evidence that leverage is not a significant factor associated with the level of AC activity, as measured by the number and duration of meetings (Collier and Gregory, 1999) or with the likelihood of a firm including a separate AC report in its annual report (Turpin and DeZoort, 1998).

\subsubsection{Other agency factors}

Within an agency framework a number of other variables have also been tested for their association with voluntary formation of ACs, but overall with no more conclusive results. For example, while some studies have found a negative relationship between the level of management ownership and AC formation (Pincus et al., 1989; Collier, 1993), others have not found any significant relationship (Bradbury, 1990; Menon and Williams, 1994; Turpin and DeZoort, 1998). Tests have also shown no significant association between the 
voluntary formation of ACs and assets in place (Bradbury, 1990; Collier, 1993; Adams, 1997), the number of shareholders (Collier, 1993), and the existence of a dominant chief executive officer (Collier, 1993). Evidence has, however, been reported of a significant negative relationship between the presence of a dominant chief executive officer and AC activity, as indicated by frequency and duration of meetings (Collier and Gregory, 1999). Although a positive relationship between national stock market listing and $\mathrm{AC}$ formation has been found (Pincus et al., 1989), suggesting that ACs may reflect the greater information and monitoring demands of the stock market investors, this influence does not hold when extended to voluntary disclosure of an AC report (Turpin and DeZoort, 1998). The existence of a large inter-corporate stockholding increases the probability that a firm will have outside directors, thereby increasing the probability that a firm maintains an AC (Bradbury, 1990).

Existence does not constitute effectiveness, and the mere formation of an AC does not mean that boards of directors actually rely on ACs to enhance their monitoring ability (Menon and Williams, 1994). Other attributes have also been tested as potential indicators of AC impact in practice. AC activity, measured by the frequency of meetings, has been found to increase with firm size and with increases in the proportion of outsiders on the board (Menon and Williams, 1994). Collier and Gregory (1999) found the number and duration of $\mathrm{AC}$ meetings to be negatively related to the presence of a dominant chief executive officer (CEO) and positively related to top $\operatorname{tier}^{2}$ audit firms. There is some evidence that companies with strong CEOs have a higher probability of placing insiders and interested directors on ACs than those with relatively weaker CEOs (Klein, 1998a) and also that the ACs of strong CEO companies tend to meet less frequently than their counterparts (Klein, 1998a; Collier and Gregory, 1999). However, the number and duration of AC meetings are very crude measures of AC activity which may depend not only on the size and nature of a company's business, but also on the scope of the AC's activities and more fundamentally on the extent and nature of communication outside AC meetings.

A further potential indicator of effectiveness that has been used to test the link between agency cost proxies and the quality of AC monitoring is the inclusion in the AC of members with relevant experience. Lee and Stone (1997) found that the composition of ACs is not related to agency costs but is significantly related to the background of the CEO and AC chair, and concluded that their evidence was inconsistent with the agency paradigm that has guided much research on monitoring and control.

Overall, the empirical evidence on the formation of, and/or reliance on, ACs provides very limited support for viewing their effects solely in terms of managing the costs associated with agency related factors. Given this conclusion, a number of suggestions, including the adoption of alternative approaches, for $\mathrm{AC}$ research are made in the final section of this paper. 


\subsubsection{Association with large auditing firms}

Auditing firms may have incentives to encourage the formation of ACs. It is argued that an AC enhances the independence of the auditor from management, which in turn can be important in protecting the auditor from allegations of inadequate auditing associated with business failure or fraud (Mautz and Neumann, 1970). Large audit firms should have more incentive to promote ACs among their clients than smaller firms, and the rate of voluntary formation for different categories of auditor could indicate a link with auditor incentives.

There is some evidence of an association between the use of top-tier audit firms and the formation of ACs. For example, evidence has been reported for the US showing a positive relationship between a company being audited by a top-tier audit firm and the existence of an AC (Pincus et al. 1989). Similarly, in circumstances where an incumbent auditor is replaced by a smaller audit firm, an AC is not likely to be formed (Eichenseher and Shields, 1985; Bradbury, 1990; Menon and Williams, 1994). Although this association is consistent with many observations on the competitive nature of the market for audit services (Pong and Turley, 1997), it need not imply causality as both the engagement of a top-tier auditor and the adoption of an AC could simply reflect other company variables. Despite finding some evidence that companies with auditors outside the top-tier were less likely to have formed ACs, Collier (1993) confirmed that having a top-tier auditor was not a significant factor influencing AC formation, although a significant positive relationship has been found between top-tier auditors and AC activity (Collier and Gregory, 1999).

\subsubsection{Legal protection}

ACs can provide evidence that the board of directors has exercised due care in performing its prescribed duties which in turn would be expected to reduce the board's legal exposure (Buckley, 1979; Maher, 1981) and there is some early evidence of a perception amongst auditors and directors, both executive and non-executive, that an AC provides some legal protection to the directors as evidence of due diligence in the fulfillment of their responsibilities (Mautz and Neumann, 1970). It has also been suggested that the increase in adoption of ACs in the US during the late 1970s was a monitoring response to increasing director liability, primarily stemming from the Foreign Corrupt Practices Act (FCPA) of 1977, and by implication that a perceived effect of ACs is lower liability costs (Eichenseher and Shields, 1985). However, the legal protection explanation of the benefits and effects of ACs is likely to be influenced by the particular legal context in different national environments and so is not compelling as a universal explanation for the development of ACs internationally. 


\subsection{EFFECTS ON THE AUDIT FUNCTION}

A second theme relevant in evaluating the governance contribution of ACs is their impact on the external and internal audit function. There are several research questions of interest in this area. Does the AC affect the selection, retention and removal of the auditor or influence the level of audit fees? Has auditor independence improved as a result of having ACs? What is the likelihood that the AC will support either the auditors or management in a dispute? How do ACs impact on the internal control and risk management processes in companies? Many of the claimed benefits of ACs are linked to these questions. This section discusses evidence dealing with such issues.

\subsubsection{Auditor selection}

A potential effect of ACs relating to external auditor appointments is that they may exhibit a bias in favour of large auditors, for example due to past connections or reputation and associated perceptions of audit quality. Evidence from early studies examining auditor selection in the US in the 1980s did not support the existence of an AC bias leading to the selection of large, better-known auditing firms over smaller, less well-known firms (Kunitake, 1981, 1983; Eichenseher and Shields, 1985; Cottell and Rankin, 1988). While there was evidence of a tendency for companies with an AC to select a toptier audit firm at the time of a change in auditor, this behavior was also exhibited in companies without an $\mathrm{AC}$ and the evidence did not suggest any statistically significant AC effect on this tendency (Eichenseher and Shields, 1985; Cottell and Rankin, 1988).

More recent research has reported that ACs which do not include employees and that meet at least twice per year are more likely to select auditors specializing in the company's industry (Abbott and Parker, 2000). Archambeault and DeZoort (2001) reported results which suggested that neither the existence of an AC nor its level of activity (proxied by the number of AC meetings) had a negative and significant relationship with auditor switches identified as suspicious. However, there was a negative and significant relationship between suspicious auditor switches and the proportion of independent directors, the proportion of AC members with experience in accounting, auditing and finance, and the size of the AC.

\subsubsection{Auditor remuneration}

A related question to that of auditor selection is the effect of ACs on auditor remuneration. Despite the considerable volume of research on audit fees, evidence of $\mathrm{AC}$ effects on fees is rather limited. One difficulty is that different rationales suggest that ACs could result in increased fees or decreased fees. If 
an $\mathrm{AC}$ seeks to enhance audit quality, the impact could be to increase the audit fee. Conversely, if existence of an AC is associated with increased internal control strength, a reduced fee would be expected. Collier and Gregory (1996) examined these propositions and found a significant positive relationship for the first but no significant relationship for the second. The authors conclude that 'there is no conclusive evidence to suggest that (ACs are) effective in engendering a stronger internal control environment that is reflected in reduced audit fees' (p.195).

Evidence that the proportion of non-executive directors has a positive and significant impact on audit fees, which is consistent with increased nonexecutive representation encouraging more extensive auditing, is provided by O'Sullivan (2000) based on an examination of the 1992 fees of 402 UK companies. Intriguingly, however, this research did not test whether the presence of an AC affects audit fees, but a study by the same author (O'Sullivan, 1999) using the 1995 audit fees for a sample of 146 UK companies found no evidence that board and AC characteristics influence audit pricing.

The potential for research on AC's involvement and influence in audit fee determination is much broader than the limited examination it has so far received. In this context it is interesting to note that DeZoort (1997) found that AC members ranked external auditor selection and fee approval as relatively unimportant compared to other oversight duties. The AC's perceptions of auditor quality will inevitably influence its approach to auditor selection and remuneration and those perceptions are influenced by AC members' prior exposure to different size audit firms (Knapp, 1991). Survey results indicate that audit team factors, such as the level of partner/manager attention given to the audit, are perceived by AC chairs to have a greater effect on audit quality than factors such as the relative significance of total fees paid to the audit firm. There is also evidence that AC members perceive that large audit firms are more likely to disclose material errors that they discover than are local firms and that a learning curve effect in the early years of an audit appointment results in a gradual improvement in auditor quality (Schroeder et al., 1986).

\subsubsection{Auditor independence}

A longstanding element in the rationale for ACs is their potential effect on the relationship between the external auditor and management and consequent benefit for auditor independence (Cohen, 1978). Some evidence on this issue is provided by studies that have examined the effect of AC existence on users' perception of independence. The presence of ACs has been found to create a perception of enhanced auditor independence and more reliable financial reporting among financial statements users (Gwilliam and 
Kilcommins, 1998). Similarly, a small sample study of 20 bankers considering loan applications has identified greater reliance on financial statements given information on the presence of ACs than given information on their absence (Tsui et al., 1994). It is, however, difficult to draw general conclusions from these exploratory and survey studies. The observed effects could be due to the fact that the subjects' attention was drawn specifically to the existence of an $\mathrm{AC}$ or otherwise, and may not represent normal decision processes in practice.

A second source of evidence on the contribution of ACs to auditor independence is their behaviour in situations where there is a dispute between the external auditor and executive management. Confidentiality limits the research potential in this area, but a limited amount of questionnaire and experimental test results are available. In an early experimental survey, Knapp (1987) examined factors affecting AC support for auditors, rather than management, in audit disputes. The results suggested that $\mathrm{AC}$ members, on average, tended to support the auditors, rather than management, in the conflict scenarios where the dispute involved objective technical standards and the auditee was in a weak financial position.

Similar more recent work identified greater independent director experience and greater audit knowledge as associated with higher AC support for an auditor who advocated a 'substance over form' approach in a dispute with client management (DeZoort and Salterio, 2000). Given the evidence of significant disagreements between executive management, external auditors, and AC chairs concerning the appropriate level of financial statement disclosure (Haka and Chalos, 1990), the effects of ACs on auditor independence may be much more complex than can easily be captured in survey studies (Spira, 1999).

\subsubsection{Audit process and reporting}

Given the adoption of new audit methodologies (Bell et al., 1997; KPMG, 1999; Lemon et al. 2000) and concerns about the external reporting of audit findings (Hatherly et al., 1998; Manson and Zaman, 2001), the impact of ACs on the external audit process and on auditor communication is an important issue. Although there is some evidence that auditors gather information on corporate governance primarily at the pre-planning and the planning stages (Cohen and Hanno, 2000), there is limited research evidence of AC impact on the audit process. Practicing auditors have characterized their meetings with the AC as normally entailing the auditor reporting on significant issues, rather than an active two-way exchange or a proactive process on the part of the AC (Cohen et al., 2002). Interestingly the auditors believed that ACs are not effective and not powerful enough to resolve contentious matters with management. 
Some indication of the effects of ACs on the outcome of the audit may be gleaned from Beattie et al.'s (2000) investigation of interactions between finance directors and audit engagement partners in the UK. The authors found that the existence of an $\mathrm{AC}$ was not associated with the extent of changes to financial statements. ACs were however found to reduce the confrontational intensity of interactions between auditors and management by increasing the level of discussion and reducing the level of negotiation. While in interviews, practicing auditors state that their discussions with ACs or boards never affect the type of audit report issued (Cohen et al., 2002), investigation of a link between $\mathrm{AC}$ independence and audit reporting has found that the greater the percentage of grey directors on the $\mathrm{AC}$, the lower the probability that the auditor will issue a going-concern audit qualification (Carcello and Neal, 2000, 2003).

\subsubsection{Internal controls and risk management}

Although numerous articles in the professional literature discuss the control and risk management roles of ACs, the academic literature on the impact of ACs in these areas is rather limited. Evidence based on experience in an individual company is provided by Allison (1994) who illustrates a case where the $\mathrm{AC}$ has become an integral element in the internal control system of an enterprise. Analysis of 11 AC reports, for the US fiscal year 1990, found that all the companies reported that their ACs review and monitor internal controls (Rezaee and Farmer, 1994, p.18). An interesting consideration in this context is the suggestion that internal auditors and managers believe that where the internal audit function is outsourced it might be difficult for ACs and boards to come to an overall opinion on the effectiveness of internal control (Assiri and Sherer, 2000).

A related question is the role of ACs in the hiring and firing of the chief internal auditor. In the US, for example, the NCFFR (1987) advocated that ACs should review the appointment and dismissal of the chief internal auditor. The limited empirical evidence on this issue, from a survey of US chief internal auditors, suggests that ACs are involved in appointment and dismissal decisions in $33 \%$ and $38 \%$ of companies, respectively (McHugh and Raghunandan, 1994). Only in $14 \%$ of such cases did the chief internal auditor have unrestricted access to the AC, and, concerning the question of independence, the authors found that a strong majority of internal auditors, particularly those in smaller companies, perceived that vesting the AC with authority over appointment and dismissal would enhance internal auditor independence, improve oversight by the $\mathrm{AC}$, and improve the ability of the internal auditor to get action on audit findings.

Some evidence is available that the more independent the AC is from executive management the more active is its approach to internal audit. This 
higher degree of activity on internal audit matters did not however extend to involvement in decisions to dismiss the chief internal auditor (Scarbrough et al., 1998). Survey evidence from auditors and directors in Singapore, where ACs are mandatory, reported that, although the existence of a strong $\mathrm{AC}$ is perceived to enhance the effectiveness of an external audit and to help the company prevent and detect errors in the financial statements, there was doubt among respondents about whether a strong AC would help the company to prevent and detect control weaknesses and fraud (Goodwin and Seow, 2002).

It has been reported that $\mathrm{AC}$ members rank internal control evaluation as the most important $\mathrm{AC}$ oversight responsibility after financial statement review (DeZoort, 1997). However, a difficulty with researching this area is identifying generalized signals of internal control impact. In an examination of whether experience affects AC members' oversight judgments, it was found that AC members with financial experience made internal control judgments more like auditors than did members without experience, suggesting that relevant expertise can make a difference in $\mathrm{AC}$ member oversight of internal controls and risk management (DeZoort, 1998).

\subsection{FINANCIAL REPORTING EFFECTS}

A further area of significant interest is the effect of ACs on financial reporting quality. The basic question is whether financial reporting is different in the presence of ACs compared to their absence. Identifying signals of financial reporting quality may be difficult but can be attempted either through analysis of actual reported financial numbers, for example to consider whether, ACs improve companies' earnings quality, or through negative signals of problems in financial reporting, for example instances of apparent or alleged errors, fraud and irregularities (see Table III). The growing volume of research in this area generally falls into two categories: studies which have examined the effect of $\mathrm{AC}$ presence (absence) on various measures of financial reporting quality (for example, DeFond and Jiambalvo, 1991; Beasley, 1996; Dechow et al., 1996; McMullen, 1996; Peasnell et al., 1999); and those more concerned with testing particular AC characteristics, such as meetings, independence and members' backgrounds (for example, Abbott et al., 2000; Abbott et al., 2000; Beasley et al., 2000; Parker, 2000; and Windram and Song, 2000).

Evidence of a positive link between $\mathrm{AC}$ existence and the quality of financial reporting has been provided by analysis indicating that earnings overstatements, as indicated by prior period adjustments to correct errors in previous reports, are less likely among companies that have ACs (DeFond and Jiambalvo, 1991) and that companies manipulating earnings are less likely to have an AC (Dechow et al., 1996). Evidence has also been 


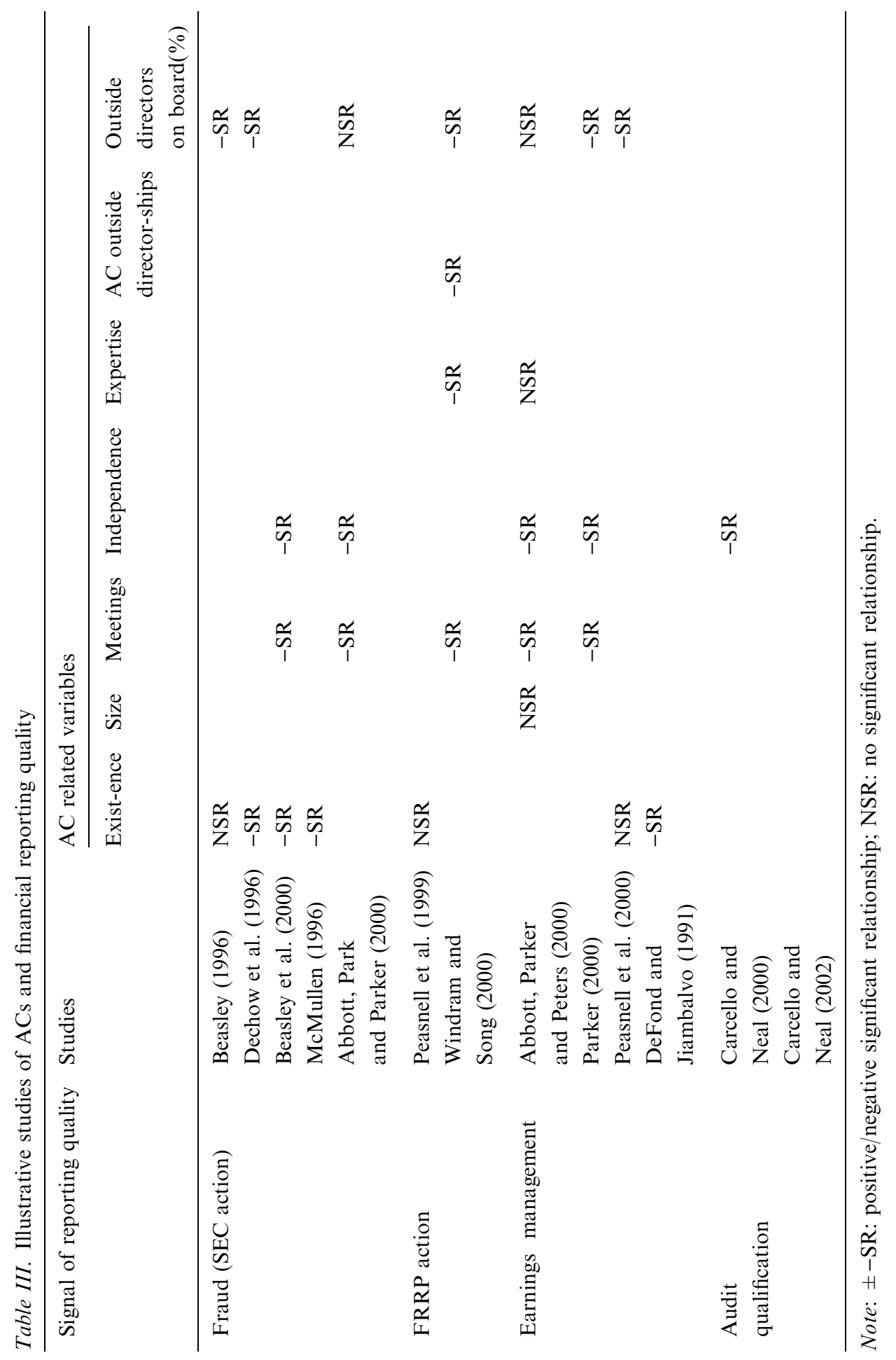


documented that ACs are associated with a reduced incidence of errors and irregularities in financial statements, as identified by a number of indicators of financial reporting quality ${ }^{3}$ (McMullen, 1996). In the UK, action against companies by the Financial Reporting Review Panel (FRRP) for defective financial statements has been used as an equivalent signal to SEC Enforcement Actions in the US. While, for a sample of $47 \mathrm{UK}$ firms subject to FRRP action, Peasnell et al. (1999) did not report a significant relationship between FRRP action and presence of ACs, Windram and Song (2000) found a significant negative relationship between FRRP action and the AC's financial literacy, the frequency of $\mathrm{AC}$ meetings and the number of outside directorships held by AC members.

What is not resolved by these studies on reporting quality is whether the improvements in financial reporting are specifically due to the existence of $\mathrm{ACs}$ or whether certain AC characteristics and reporting outcomes are both the product of other corporate variables. A particularly interesting finding relating to this is that the presence of ACs does not significantly affect the likelihood of fraud (Beasley, 1996), although the proportion of outside members on the board of directors was found to be lower for firms experiencing financial statement fraud than for no-fraud firms and a significant negative relationship was also found between the likelihood of fraud and both the percentage of grey directors on the board and the percentage of independent directors. Although based on a small sample of only $26 \mathrm{com}-$ panies, the results suggest board composition, rather than the presence of ACs, may be significantly more likely to reduce the likelihood of financial statement fraud.

In the UK context, the association between board composition and earnings management activity in both the pre- and post-Cadbury periods has been examined (Peasnell et al., 2000). Results for the post-Cadbury period indicate less income-increasing accrual management to avoid earnings losses or earnings declines when the proportion of non-executive directors is high. However, no evidence was found of an association between the degree of accrual management and the proportion of non-executive directors in the pre-Cadbury period. Consistent with Beasley's (1996) finding, it appears the proportion of non-executive directors is significant in explaining reduced earnings management rather than the increasing use of ACs in the post-Cadbury period (Peasnell et al., 2000).

Neither of the above studies examined the effect of AC characteristics, but evidence is now being reported that these are important in explaining, inter alia, cross-sectional differences in financial reporting quality (Wright, 1996; Klein, 2002; Abbott et al., 2000; Abbott et al., 2000; Parker, 2000). Analyst ratings of financial reporting quality are higher for companies with lower percentages of directors, particularly AC members, who are either relatives of officers or have some business relationships with the firm, i.e. grey directors; 
and firms violating SEC reporting standards have a significantly higher percentage of insiders and grey directors on their AC (Wright, 1996). AC independence has also been found to be positively related to the informativeness of financial accounting information for equity valuation and negatively related to the degree of bargaining power that the CEO commands over the board (Klein, 2002).

Recent studies have reported that independent and active ACs are associated with a decreased likelihood of both fraud and non-fraudulent earnings misstatements (Abbott et al., 2000; Abbott et al., 2000), but also that AC size and $\mathrm{AC}$ expertise are not significantly related to reduced earnings misstatements (Abbott et al., 2000). Similarly, income-increasing accounting has been found to be constrained by independent ACs and by public disclosure of ACs responsibility for monitoring financial reports (Parker, 2000). Among companies subject to SEC AAERs, Beasley et al. (2000) found that fraud firms have fewer ACs, less independent ACs, fewer AC meetings and less internal audit support than non-fraud firms.

While some of the variables representing $\mathrm{AC}$ characteristics have been associated with mixed findings, it is noticeable that both $\mathrm{AC}$ meetings (a measure of AC activity) and the independence of AC members have consistently been found to be associated with a lower likelihood of problems in financial reporting quality (see Table III). The fact that corporate failures and irregularities occur in companies with ACs complying with, or even exceeding, recommended best practice illustrates the importance of understanding the process associated with AC operations. For example, Enron provides an example which counters the proposition that financial literacy among AC members will lead to effectiveness (Benston and Hartgraves, 2002). While ACs may be enhanced by certain characteristics (such as independence and expertise), these attributes alone are unlikely to deliver an improvement in financial reporting quality. This conclusion indicates that the character and operations of ACs may be fruitful areas for research into the conditions under which the anticipated benefits of ACs can be realized.

\subsection{CORPORATE PERFORMANCE EFFECTS}

A final area of potential AC impact is corporate performance. As noted earlier, it is important to be clear whether particular benefits or effects are due to the existence of ACs as such or if they are a result of other features of corporate governance. A growing body of literature has examined the relationship between board characteristics and corporate performance. Positive findings on this issue could imply that ACs, being a subcommittee of the board with a majority of outside directors, might lead to similar performance effects. 
Taking as a starting point the idea that good corporate governance is equated with good corporate performance, some researchers have examined whether the inclusion of outside directors on the board enhances corporate performance and the returns to shareholders (Klein, 1998b). Examples of the available evidence relevant to this issue include the finding that the stock market reaction to announcements of poison pills is positive when the board has a majority of outside directors and negative when it does not (Brickley et al., 1994), and that characteristics of the board of directors' and ownership structure are significant determinants of the likelihood that a firm is a target of hostile take-over attempts (Shivdasani, 1993). Results of this nature are consistent with the proposition that outside directors do perform an important role in corporate governance and serve the interests of shareholders.

A relevant avenue of research concerning possible AC impact on performance, though not one yet fully-exploited, is the investigation of the links between board membership characteristics and shareholder wealth effects. As an example, in a study of the returns to shareholders of bidding firms in tender offers, Byrd and Hickman (1992) reported that the average announcement date abnormal return is significantly less negative for bidding firms on whose boards at least half the seats are held by independent outside directors. Examination of the wealth effects associated with appointments of an outside director by management indicates that the appointment is accompanied, on average, by significantly positive excess returns, although most boards are numerically dominated by outsiders before the appointment. This suggests that outside directors are viewed as likely to act in the interests of shareholders (Rosentein and Wyatt, 1990).

Future research on the relationship between ACs and corporate performance should also recognise the conclusions from other general reviews addressing the relationship between board composition, board leadership structure and corporate performance. Dalton et al. (1998) found little consistency in results and concluded that, in general, neither board composition nor board leadership structure has been consistently linked to corporate financial performance. This view is supported by Weisbach and Hermalin's (2000) conclusion, based on a survey of the economic literature on boards of directors, that board composition is not related to corporate performance, although board size is negatively related to corporate performance.

Some evidence on the wealth effects specifically related to ACs is provided by Wild $(1994,1996)$ in his test of the proposition that the formation of the $\mathrm{AC}$ enhances earnings quality. It was hypothesised that if the $\mathrm{AC}$ enhances the quality of reported earnings, then release of earnings reports after AC formation would be accompanied by greater revisions in users' expectations of future company performance than before the formation of the AC. The findings indicate a significant increase in stock returns variability, specifically 
$20 \%$ greater than for earnings reports prior to AC formation, leading to a conclusion that the "evidence is characteristic of effective audit committees that substantially enhance the quality of reported earnings" (p.274).

\section{Summary and Conclusions}

In an environment where, following a number of major corporate scandals, $\mathrm{AC}$ effectiveness has been criticized and changes are being introduced to strengthen the AC's governance contribution, understanding the existing body of evidence concerning the effects of ACs is important - for formulating expectations regarding the likely impact of policy changes and for establishing the benchmark for testing the impact of those changes. Taken together, the evidence discussed in the previous Section suggests a number of general observations concerning the development of future research priorities of relevance to these questions that can help inform the continuing debate on regulatory policy and its implementation in practice.

\subsection{RESEARCH FOCUS}

Attempts to infer perceived benefits by examining the structural incentives associated with choices over AC adoption and characteristics do not suggest a clear accepted model of the role of ACs in corporate governance in practice. In part this may be due to the weakness of proxy measures used to represent and test different governance scenarios, but it also indicates the need to dig deeper to develop a more complete understanding of the ACs in practice.

The predominant emphasis in extant research is on testing incentives for the use of ACs within an agency framework, where the underlying proposition is that an effect of the AC will be to reduce agency costs. Overall, however, the empirical evidence that the use of ACs is intended to achieve a reduction in agency costs is very limited. It is unsurprising that certain company characteristics, used as proxies for agency costs, are correlated strongly with the adoption of ACs, and the existence of such a relationship does not point unambiguously to motives for the use of ACs. Important research issues include the interaction between ACs and other aspects of governance arrangements, particularly attributes of board composition in general and why, even if ACs do indeed reduce agency costs, preference is given to ACs over other means of achieving the same goal. It could be important to establish whether the effects on external audit, financial reporting and corporate performance are simply due to the mix of insiders and outsiders on the board or whether particular governance structures such as ACs really make a difference.

There is considerable scope for further study of AC effects on all aspects of the audit and financial reporting process. The evidence on the link between 
$\mathrm{AC}$ presence, and more recently $\mathrm{AC}$ characteristics, and financial reporting quality raises some important questions. It also remains the case that there are a number of areas of potential impact on which as yet only limited evidence is available. Such areas include the effect of ACs on aspects of internal control, internal audit and risk management. Similarly, although the research on board composition suggests that ACs, as a subcommittee of the board, may fulfill a useful role, it does not provide direct evidence of AC impact on corporate performance.

Even where evidence has been found of association between ACs and governance outcomes, there remains very little understanding of the methods of operation whereby these effects are brought about. Policy on ACs has tended to emphasise characteristics of the committee and its members, but the processes through which the AC's activities are conducted and the impact on other organizational processes and the behaviour of other participants are of at least equal importance. Extant research provides very little understanding of these processes. While there is some evidence of a correlation between financial reporting characteristics and governance arrangements, further research is needed to establish issues relating to the processes and impact unique to ACs.

A limiting feature of much of what has been researched on ACs is that it has resulted from studies in which the primary subject has not been ACs but rather topics such as auditor independence, auditor tenure and financial reporting quality. In such studies, researchers tend merely to add an AC variable to their model of, for example, audit fees or financial reporting quality. The fact that $\mathrm{AC}$ issues are often a secondary concern in the research design inevitably limits the contribution of such studies to the understanding of AC operations and effects. ACs should be the primary subject of future research, rather than simply another variable included in a model.

\subsection{RESEARCH FRAMEWORK - NEED TO RECONCEPTUALISE ACS}

The evaluation of the evidence of AC effects suggests that there is a case for focusing attention on the institutional and organizational features, particularly the dynamics relating to the AC process that lead to certain effects. Clearly there are variations in the degree of effectiveness between ACs and the context and nature of AC activities that appear to be associated with particular effects need to be investigated more fully. This issue might require rather different types of research than those that have so far been prominent. It could be said that much of the research to date has been developed around theories of the existence of ACs but that for the future there is a need to give greater attention to possible theories of operation. 
The fact that extant research has primarily adopted an agency perspective may have to some extent constrained insights about the operation of ACs and how the manner in which AC activity is conducted is linked to impact in corporate enterprises. ACs do not operate in a vacuum and their operation and effects cannot be adequately examined without regard to the institutional and organizational context in which they function and the power relationships which are intrinsic to that context.

The ways in which ACs affect behaviour within organisations is an open and potentially interesting area for future research. AC effects need to be examined in the context in which they operate so that due account can be taken of the relational dynamics in and around the $\mathrm{AC}$, and the interaction of the $\mathrm{AC}$ with other internal structures of the entity. It should also be recognised that the personality of AC members, particularly that of the AC chair, and the underlying corporate culture are potentially important factors affecting the operation and effects of ACs. Within the individual organization, these factors may be particularly important in determining AC impact and their link to $\mathrm{AC}$ effects warrants investigation.

\subsection{A CASE FOR QUALITATIVE METHODS}

Much of the existing body of AC research has been based on large samples, utilising publicly available and/or questionnaire data which rarely reflect the practical reality of ACs' operation and their effects. The impact of ACs cannot be adequately investigated using solely questionnaire surveys and analysis of databases. Qualitative research methods incorporating case studies and interviews provide significant potential for researching ACs' activities in the organizational and institutional context in which they operate. In particular, cases may allow identification of specific independence and audit process effects and recognition of the complex environment of the AC and the interaction of the AC with other parties such as executive management and auditors. There are a number of reasons for believing this area of effect could be of particular significance.

First, in the context of the debate on corporate governance, the interaction between the AC and auditors is potentially an important means of enhancing overall governance. The issues surrounding auditor independence and the appointment and retention of auditors, including the negotiation of fees and the provision of non-audit services, need to be examined in more detail. Second, communication between the AC and auditors clearly has the potential to influence auditors' work programmes, both through direct suggestion and through the onus it places on auditors to be able to justify their intended approach. Potentially the audit process is made more visible than previously. Third, as the methodologies employed by the audit firms continue to evolve, and particularly in recent years as a tension has arisen between the 
'attest' and 'consultancy' attributes of the audit (Jeppesen, 1998), the degree to which the methodologies meet the expectations of ACs will be of interest. Finally, in exercising influence over both internal control and external audit there are different potential strategies available to ACs, with varying implications for external audit. How ACs make relevant choices and the circumstances in which, for instance, external audit costs are increased or decreased should be investigated.

\subsection{CONCLUDING REMARKS}

It is clear that there is no automatic relationship between the adoption of AC structures or characteristics and the achievement of particular governance effects. The mixed results associated with, for example, tests for association between ACs and aspects of the audit function and the quality of financial reporting suggest that particular rules on ACs cannot be relied upon to deliver a consistent impact. This observation is of relevance in the policy arena at a time when greater reliance is being placed on codification around such factors as AC members' independence and expertise as the means of "correcting" past weaknesses in the arrangements for ACs. That is not to say that such characteristics are not valuable and worthy of promotion but caution may be needed over expectations that greater standardization will deliver guaranteed standard governance contributions.

This paper has sought to illustrate and evaluate the nature and extent of available empirical evidence of the governance impact of ACs, through the benefits apparent in the structural incentives for the adoption of ACs and their effects on the audit function, on financial reporting quality and on corporate performance. Evaluation of this evidence offers a mixed picture while some evidence of beneficial effects has been established, on many areas of expected benefits the findings thus far are either inconclusive or very limited, leaving plenty of scope for further investigation. Future research should incorporate (i) greater consideration of the organizational and institutional contexts in which ACs operate; (ii) explicit theorization of the processes associated with AC operation; (iii) complementing extant research methods with field studies; and (iv) investigation of unintended (behavioural) as well as expected consequences of ACs.

\section{Appendix}

"Increasingly, companies will be expected to demonstrate good governance in order to access the world's capital markets. The fact that a company has an audit committee may boost investor confidence in its governance practice" (Price Waterhouse, 1997). 
"There is no doubt that audit committees can play a major role in bringing about greater accountability by companies and in restoring confidence in financial reporting" (Lindsell, 1992).

"(Audit committees can) help directors meet their statutory and fiduciary responsibilities, especially as regards accounting records, annual accounts and the audit" (Collier, 1992).

"An audit committee is unique in that it provides a forum where directors, management and auditors can deal together with issues relating to the management of risk and with financial reporting obligations" (AARF, 1997).

"The independent nature of the audit committee should result in the internal audit department assuming a greater responsibility in the financial reporting process. This role should, in turn, promote improvements in the internal control structure, resulting in heightened integrity in the financial reporting process" (Apostolou, 1990).

"(Audit committees) provide a framework within which the external auditor can assert his independence in the event of a dispute with management (and) strengthen the position of the internal audit function, by providing a greater degree of independence from management" (Cadbury, 1992).

"Audit committees have an important role to play in enhancing the perceived independence of internal and external audit" (Price Waterhouse, 1997).

"The audit committee of a company's board of directors can play a crucial role in preventing and detecting fraudulent reporting." (NCFFR, 1987).

"(Audit committees have the potential to) improve the quality of financial reporting, by reviewing the financial statements on behalf of the board (and to) create a climate of discipline and control which will reduce the opportunity for fraud" (Cadbury, 1992).

\section{Notes}

1 There are significant differences between the private sector and public sector contexts within which ACs have been established. These differences are particularly marked with respect to the institutional and governance arrangements the $\mathrm{AC}$ is intended to contribute to and the current governance climate in which the role of ACs is being developed. For this reason the current paper focuses on private sector organizations alone.

2 The term "top-tier" refers generically to the leading group of firms that currently comprise the Big- 4 , and previously over time the Big-5, Big- 6 or Big- 8 audit firms.

3 These are shareholder litigation alleging fraudulent financial reporting; correction of reported quarterly earnings; SEC enforcement actions; illegal acts; and auditor turnover involving a client-auditor accounting disagreement.

\section{References}

AARF: 1997, Audit Committees: Best Practice Guide, Australia: Australian Accounting Research Foundation, Australian Institute of Company Directors and Institute of internal Auditors. 
Abbott, L.J. and S. Parker: 2000, "Auditor selection and audit committee characteristics", Auditing: A Journal of Practice \& Theory 19(2): 47-66.

Abbott, L.J., S. Parker, and G. F. Peters: 2000, “The Effectiveness of Blue Ribbon Committee Recommendations in Mitigating Financial Misstatements: An Empirical Study, Working Paper (Draft 1.1 / November 2000), Santa Clara University.

Abbott, L.J., Y. Park, and S. Parker: 2000 "The effects of audit committee activity and independence on corporate fraud", Managerial Finance 26(11): 55-67.

Adams, M.: 1997, "Determinants of Audit Committee Formation in the Life Insurance Industry: New Zealand Evidence", Journal of Business Research 38(2): 123-129.

Allison, D.L.: 1994, "Internal Auditors and Audit Committees", Internal Auditor, February, pp. 50-55. APB 1994 The Audit Agenda, London: Auditing Practices Board.

Apostolou, B.: 1990, The role of Internal Auditor Communication with the Audit Committee", Internal Auditing Fall 6(2): 35-42.

Archambeault, D. and T. DeZoort: 2001, "Auditor Opinion Shopping and the Audit Committee: An Analysis of Suspicious Auditor Switches", International Journal of Auditing 5: $33-52$.

Assiri, S.M. and M. Sherer: 2000, "Outsourcing the internal audit function: an empirical evaluation of benefits and pitfalls", Paper presented at the Sixth Annual Midyear AAA Auditing Section Conference, California.

Australian Treasury: 2002, Corporate Disclosure: Strengthening the Financial Reporting Framework. CLERP9, Department of Treasury, Commonwealth of Australia. http:// www.treasury.gov.au.

Beasley, M.S.: 1996, "Board of Director Composition and Financial Statement Fraud", Accounting Review 71(4): 443-465.

Beasley, M.S., J.V., Carcello, D.R. Hermanson, and P.D. Lapides: 2000, "Fraudulent Financial Reporting: Consideration of Industry Traits and Corporate Governance Mechanisms", Accounting Horizons 14(4): 441-454.

Beattie, V., S. Fearnley, and R. Brandt: 2000, "Behind the Audit Report: A Descriptive Study of Discussions and Negotiations Between Auditors and Directors", International Journal of Auditing 4: 177-202.

Bell, T., F. Morris, I. Solomon, and H. Thomas: 1997, Auditing Organizations Through a Strategic- Systems Lens, Montvale, NJ: KPMG Peat Marwick LLP.

Benston, G.J. and A.L. Hartgraves: 2002, "Enron: What Happened and What We can Learn from it", Journal of Accounting and Public Policy 21: 105-127.

Blue Ribbon Committee: 1999, Report and Recommendations of the Blue Ribbon Committee on Improving the Effectiveness of Corporate Audit Committees (NY: NYSE and NASD).

Bradbury, M.E.: 1990 “The Incentives for Voluntary Audit Committee Formation”, Journal of Accounting and Public Policy 9: 19-36.

Brickley, J.A., J.L. Coles, and R.L. Terry: 1994, "Outside Directors and the Adoption of Poison Pills", Journal of Financial Economics 35: 371-390.

Cadbury Committee: 1992, Financial Aspects of Corporate Governance (London: Gee Publishing Ltd).

Carcello, J.V. and T.L. Neal: 2000, “Audit Committee Composition and Auditor Reporting", Accounting Review 75(4): 453-467.

Carcello, J.V. and T.L. Neal: 2003, “Audit Committee Characteristics and Auditor Dismissals Following 'new' Going-concern Reports”, Accounting Review 78(1): 95-118.

Cohen Commission: 1978, Report of the Commission on Auditors' Responsibilities, AICPA.

Cohen, J. and D. Hanno: 2000, "Auditors Consideration of Corporate Governance and Management Philosophy in Preplanning and Planning Judgments", Auditing: A Journal of Practice \& Theory 19(2): 133-146. 
Cohen, J., G. Krishnamoorthy, and A.M. Wright: 2002, "Corporate Governance and the Audit Process", Contemporary Accounting Research, 19(4): 573-94.

Collier, P.: 1992, Audit Committees in Large UK Companies, (London: ICAEW Research Board).

Collier, P.: 1993, "Factors affecting the formation of audit committees in major UK listed companies", Accounting and Business Research 23(91A): 421-430.

Collier, P.: 1996, "The Rise of the Audit Committee in UK Quoted Companies: A Curious Phenomenon?", Accounting, Business and Financial History 6(2): 121-140.

Collier, P. and A. Gregory: 1996, "Audit Committee Effectiveness and the Audit Fee", European Accounting Review 5(2): 177-198.

Collier, P. and A. Gregory: 1999, "Audit Committee Activity and Agency Costs", Journal of Accounting and Public Policy 18: 311-332.

COSO: 1994, Internal Control - Integrated Framework. New York: Coopers and Lybrand / Committee of Sponsoring Organizations of the Treadway Commission.

Cottell, P.G. and L.J. Rankin: 1988, Do Audit Committees Bias Auditor Selection?", Akron Business and Economic Review, Winter 19(4): 87-103.

Dalton, D.R., C.M. Daily, A.E. Ellstrand, and L.J. Johnson: 1998, "Meta-analytic Review of Board Composition, Leadership Structure and Financial Performance", Strategic Management Journal 19: 269-290.

Dechow, P. M., R.G. Sloan and A.P. Sweeney: 1996, Causes and Consequences of Earnings Manipulation: An Analysis of Firms Subject to Enforcement Action by the SEC", Contemporary Accounting Research, Spring 13(1): 1-36.

DeFond, M.L. and J. Jiambalvo: 1991, "Incidence and Circumstances of Accounting Errors", Accounting Review, July 66(3): 643-655.

DeZoort, F.T.: 1997, “An Investigation of Audit Committees' Oversight Responsibilities", Abacus 33(2): 208-227.

DeZoort, F.T.: 1998, “An Analysis of Experience Effects on Audit Committee Members' Oversight Judgments", Accounting Organizations and Society 23(1): 1-21.

DeZoort, F.T. and S. Salterio: 2000, "The Effects of Corporate Governance Experience and Financial Reporting and Audit Knowledge on Audit Committee Members' Judgments", Working Paper, University of South Carolina.

Eichenseher, J. W. and D. Shields: 1985, "Corporate Director Liability and Monitoring Preferences", Journal of Accounting and Public Policy 4: 13-31.

Fama, E. and M. Jensen: 1983, "Separation of Ownership and Control", Journal of Law and Economics 26: 301-325.

Goodwin, J. and J.L. Seow: 2002, "The Influence of Corporate Governance Mechanisms on the Prevention and Detection of Control Weaknesses, Fraud and Error: The Perceptions of Auditors and Directors", Accounting \& Finance 42: 195-233.

Guy, D. M. and S.A. Zeff: 2002, "Independence and Objectivity: Retired Partners on Audit Committee", CPA Journal July: 31-34.

Gwilliam, D. and M. Kilcommins: 1998, "The Impact of Audit Firm Size and Audit Committee on Perceptions of Auditor Independence and Financial Statement Reliability in Ireland", Irish Accounting Review 5(1): 23-56.

Haka, S. and P. Chalos: 1990, "Evidence of Agency Conflict Among Management, Auditors, and the Audit Committee Chair", Journal of Accounting and Public Policy 9: 271-292.

Hatherly, D.: 1999, The Future of Auditing: The Debate in the UK", European Accounting Review 8(1): 51-65.

Hatherly, D., J. Innes and T. Brown: 1998, "Free-form Reporting and Perceptions of the Audit", British Accounting Review 30(1): 23-38. 
Higgs: 2003, Review of the role and effectiveness of non-executive directors. London: Department of Trade and Industry.

ICAEW: 1997, Audit Committees: A Framework for Assessment (London: ICAEW Audit Faculty).

Jensen, M.C. and W.H. Meckling: 1976, "Theory of the Firm: Managerial Behavior, Agency Costs and Ownership Structure", Journal of Financial Economics 3(4): 305-360.

Jeppesen, K.K.: 1998, "Reinventing Auditing, Defining Consulting and Independence", European Accounting Review 7(3): 517-541.

Kalbers, L.P. and T.J. Fogarty: 1993, "Audit Committee Effectiveness: An Empirical Investigation of the Contribution of Power", Auditing: A Journal of Practice \& Theory 12(1): 24-49.

Kalbers, L.P. and T.J. Fogarty: 1998, “Organizational and Economic Explanations of Audit Committee Oversight”, Journal of Managerial Issues 10(2): 129-151.

Klein, A.: 1998a, "Economic Determinants of Audit Committee Composition and Activity", Stern School of Business Working Paper, New York University.

Klein, A.: 1998b, "Firm Performance and Board Committee Structure", Journal of Law and Economics 41: 275-303.

Klein, A.: 2002, "Audit Committee, Board of Directors Characteristics and Earnings Management", Journal of Accounting and Economics 33: 375-401.

Knapp, M.C.: 1987, “An Empirical Study of Audit Committee Support for Auditors Involved in Technical Disputes with Client Management", Accounting Review 62(3): 578-588.

Knapp, M.C.: 1991, "Factors that Audit Committee Members use as Surrogates for Audit Quality", Auditing: A Journal of Practice \& Theory 10(1): 35-52.

KPMG: 1999, The Financial Statement Audit: Why a New Age Requires an Evolving Methodology (Montvale, NJ: KPMG LLP).

Kunitake, W.: 1981, "Do Audit Committees Favor the Large CPA Firms", Journal of Accountancy August: 43-45.

Kunitake, W.: 1983, "Auditor Changes by Audit Committees and Outside Directors", Akron Business and Economic Review, Fall: 48-52.

Lee, T.: 2001, "A Crisis of Confidence: US Auditing in the 21st Century", International Journal of Auditing 5(1): 1-2.

Lee, T. and M. Stone: 1997, "Economic Agency and Audit Committees: Responsibilities and Membership Composition", International Journal of Auditing 1(2): 97-116.

Lemon, W.M., K.M. Tatum and W.S. Turley: 2000, Developments in the Audit Methodologies of Large Accounting Firms. London: Auditing Practices Board.

Lindsell, D.: 1992, "Blueprint for an Effective Audit Committee", Accountancy, December, p. 104.

Manson, S. and M. Zaman: 2001, Auditor Communication in an Evolving Environment: Going Beyond SAS 600 Auditors' Reports on Financial Statements", British Accounting Review 33: 113-136.

Marsh, H.L. and T.E. Powell: 1989, "The Audit Committee Charter: Rx for Fraud Prevention", Journal of Accountancy February: 5-57.

Mautz, R.K. and F.L. Neumann: 1970, Corporate Audit Committees. Illinois: Bureau of Economic and Business Research, University of Illinois.

McHugh, J. and K. Raghunandan: 1994, "Hiring and Firing the Chief Internal Auditor", Internal Auditor August: 34-39.

McMullen, D.A.: 1996, “Audit Committee Performance: An Investigation of the Consequences Associated with Audit Committees", Auditing: Journal of Practice \& Theory 15(1): 87-103.

Menon, K. and J.D. Williams: 1994, "The Use of Audit Committees for Monitoring", Journal of Accounting and Public Policy 13: 121-139. 
Morse, A. and M. Keegan: 1999, Audit Committees: Good Practices for Meeting Market Expectations. London: PricewaterhouseCoopers.

NCFFR: 1987, Report of the National Commission on Fraudulent Financial Reporting (Treadway Commission) (New York: AICPA).

O’Sullivan, N.: 1999, "Board Characteristics and Audit Pricing Post-Cadbury: A Research Note", European Accounting Review 8(2): 253-263.

O'Sullivan, N.: 2000, "The Impact of Board Composition and Ownership on Audit Quality: Evidence From Large UK companies”, British Accounting Review 32(December), 397-414.

Parker, S.: 2000, "The association between audit committee characteristics and the conservatism of financial reporting", Paper presented at the American Accounting Association 2000 Annual Conference.

Peasnell, K.V., P. Pope, and S. Young: 1999, “Characteristics of Firms Subject to Adverse Financial Reporting Review Panel Rulings", Paper presented at the Financial Accounting and Auditing Research Conference, 12-13 July, SOAS, University of London.

Peasnell, K.V., P. Pope, and S. Young: 2000, “Accrual Management to Meet Earnings Targets: UK Evidence Pre- and Post Cadbury", British Accounting Review, 32(December), 415-445.

Pincus, K., M. Rusbarsky, and J. Wong: 1989, "Voluntary Formation of Corporate Audit Committees Among NASDAQ firms", Journal of Accounting And Public Policy 8: 239-65.

Pong, C. and S. Turley: (1997) "Audit Firms and the Market", In M. Sherer and S. Turley (eds.), Current Issues in Auditing, London: Paul Chapman.

Powers Report (2002) Report of Investigation by the Special Investigative Committee of the Board of Directors of Enron Corp., February.

Price Waterhouse (1997) Audit Committees - A Study in European Corporate Governance. London: Price Waterhouse.

Rezaee, Z. and L.E. Farmer: 1994, "The Changing Role of the Audit Committee", Internal Auditor Spring, 10-20.

Rosentein, S. and J.G. Wyatt: 1990, "Outside Directors, Board Iindependence, and Shareholder Wealth", Journal of Financial Economics 26: 175-191.

Scarbrough, D.P., D.V. Rama and K. Raghunandan: 1998, “Audit Committee Composition and Interaction with Internal Auditing: Canadian Evidence", Accounting Horizons 12(1): $51-62$.

Schroeder, M.S., I. Solomon and D. Vickrey: 1986, “Audit Quality: The Perceptions of Audit Committee Chairpersons and Audit Partners", Auditing: A Journal of Practice \& Theory 5(2): 86-94.

SEC: 2002, Disclosure Required by Section 404, 406 and 407 of the Sarbanes-Oxley Act of 2002, Securities and Exchange Commission Release No. 33-8138. http://www.sec.gov/rules/ proposed/33-8138.htm.

Sherer, M. and D. Kent: 1983, Auditing and Accountability. London: Pitman.

Shivdasani, A.: 1993, "Board Composition, Ownership Structure, and Hostile Take-overs", Journal of Accounting and Economics 16: 167-198.

Smith Committee (2003) Audit Committees - Combined Code Guidance, Financial Reporting Council.

Sommer, A.A.: 1991, “Auditing Audit Committees: An Educational Opportunity for Auditors", Accounting Horizons 5(2): 91-93.

Spira, L.: 1999, "Independence in Corporate Governance: The Audit Committee Role", Business Ethics: A European Review 8(4): 262-273.

Tricker, R.I.: 1978, The Independent Director: A study of the non-executive director and of the audit committee. Croydon: Tolley. 
Tsui, J., Subramaniam, N. and J.S. Hoy: 1994, “The Effects of Audit Committees on Bankers' Perceptions of Auditor Independence", Corporate Governance: An International Review, April, 2(2): 101-107.

Turley, S. and M. Zaman: 2003, Public Policy on Corporate Audit Committees: Case Study Evidence of Current Practice. Occasional Research Paper No. 35, Association of Chartered Certified Accountants, London.

Turnbull: 1999, Internal Control: Guidance for directors of listed companies incorporated in the $U K$, London: ICAEW.

Turner, L.E.: 2001, "Audit Committees: A Call for Action. Speech delivered at the Conference on Accounting Irregularities II: What's an Audit Committee To Do?", 21 February 2001, Atlanta, Georgia.

Turpin, R.A. and F.T. DeZoort: 1998, "Characteristics of Firms that Include an Audit Committee Report in their Annual Report", International Journal of Auditing 2: 35-48.

Vicknair, D., K. Hickman and K.C. Carnes: 1993, "A Note on Audit Committee Independence: Evidence from the NYSE on "grey" Area Directors", Accounting Horizons, Mar, 7(1): $53-7$.

Weisbach, M.S. and B.J. Hermalin: 2000, "Board of Directors as an Endogenously Determined Institution: A Survey of the Economic Literature", Working Paper, University of Illinois.

Wild, J.: 1994, "Managerial Accountability to Shareholders: Audit Committees and the Explanatory Power of Earnings for Returns", British Accounting Review 26: 353-374.

Wild, J.: 1996, "The Audit Committee and Earnings Quality", Journal of Accounting, Auditing \& Finance 11(2): 247-276.

Windram, B. and J. Song: 2000, "The Effectiveness of Audit Committees: Evidence from UK Companies in the Post-Cadbury Period", Paper presented at the British Accounting Association Annual Conference, University of Exeter.

Wolnizer, P.W.: 1995, Are Audit Committees Red Herrings?", Abacus 31(1): 45-66.

Wright, D.W.: 1996, "Evidence on the Relation between Corporate Governance Characteristics and the Quality of Financial Reporting", Working Paper, University of Michigan.

Zaman, M.: 2001, "Turnbull - Generating Undue Expectations of the Corporate Governance Role of Audit Committees", Managerial Auditing Journal 16(1): 5-9. 